\title{
MICROBIAL ACTIVITIES IN SOILS CULTIVATED WITH TRANSGENIC MAIZE EXPRESSING Bacillus thuringiensis CRY1AB AND CRY1F GENES
}

\author{
CHRISTIANE ABREU DE OLIVEIRA ${ }^{1}$, GIOVANNA MOURA CALAZANS², \\ JOSÉ EDSON FONTES FIGUEIREDO ${ }^{1}$, SIMONE MARTINS MENDES ${ }^{1}$, \\ ELIANE APARECIDA GOMES ${ }^{1}$, ROSÂNGELA CRISTINA MARUCCI ${ }^{4}$, \\ PAULO AFONSO VIANA ${ }^{1}$, LUCY SELDIN ${ }^{3}$ and IVANILDO EVÓDIO MARRIEL ${ }^{1}$
}

\author{
${ }^{1}$ Embrapa Maize and Sorghum, Sete Lagoas, MG, Brazil-christiane.paiva@embrapa.br, jose.edson@embrapa.br, \\ simone.mendes@embrapa.br,eliane.gomes@embrapa.br,paulo.viana@embrapa.br,ivanildo.marriel@embrapa.br \\ 2UNIFEMM, Sete Lagoas, MG, Brazil-giovannacalazans@hotmail.com \\ ${ }^{3}$ Federal University of Rio de Janeiro, Rio de Janeiro, RJ, Brazil - lseldin@micro.ufrj.br \\ ${ }^{4}$ Federal University of Lavras, Lavras, MG,Brazil-rosangelac.marucci@ufla.den.br
}

Revista Brasileira de Milho e Sorgo, v.14, n.3, p. 409-419, 2015

\begin{abstract}
The Brazilian acreage planted with genetically modified (GM) maize expressing Cry genes derived from the soil bacterium Bacillus thuringiensis (Bt) has increased from 4.9\% (5.0 million hectares) of total area planted in 2009 to $81.4 \%$ (15.83 million hectares) in 2014. However, studies on the effects of Bt-maize technology on nontarget microorganisms in tropical soils are incipient. Thus, a field experiment was performed to assess the physiological activity of bacterial communities associated with Bt-maize genotypes planted in tropical Dark Red Latosol of Cerrado and lowland hydromorphic soil with localized flooding. A non-transgenic hybrid (30F35) and its transgenic counterparts 30F35Y (Cry1 Ab) and 30F35H (Cry1F) were planted in a randomized block design with four replicates. Rhizosphere and non-rhizosphere soils collected from plants in the flowering stage were assayed for metabolic diversity with Biolog and enzyme activities of urease, arginase, acid phosphatase and alkaline phosphatase. Rhizosphere soil showed higher microbial activity and no significant differences were detected among genotypes in all the biochemical soil parameters evaluated. The results suggested that Bt-maize does not negatively impact the microbial community of tropical soils. Keywords: Bt-maize, functional diversity, bio-indicators, soil quality, non-target organisms.
\end{abstract}

\section{ATIVIDADE MICROBIANA EM SOLOS CULTIVADOS COM MILHO TRANSGÊNICO EXPRESSANDO OS GENES Bacillus thuringiensis CRY1AB E CRY1F}

RESUMO - A área brasileira plantada com milho geneticamente modificado (GM) expressando genes Cry derivados da bactéria do solo Bacillus thuringiensis (Bt) aumentou de 4,9\% (5,0 milhões de hectares) da área total plantada em 2009 para 81,4\% (15,83 milhões de hectares) em 2014. No entanto, estudos sobre os efeitos da tecnologia $B t$-milho sobre microrganismos não alvo em solos tropicais são incipientes. Dessa forma, foi realizado experimento de campo para avaliar a atividade fisiológica das comunidades bacterianas associadas com genótipos de milho Bt plantados em Latossolo Vermelho Escuro do Cerrado e solos hidromórficos da planície com inundações localizadas. Um híbrido não transgênico (30F35) e seus homólogos transgênicos 30F35Y (Cry1Ab) e 30F35H (Cry1F) foram plantados com delineamento de blocos casualizados com quatro repetições. Solos rizosféricos e não rizosféricos coletados de plantas no estádio de florescimento foram submetidos aos ensaios de diversidade metabólica com Biolog e atividades enzimáticas de urease, arginase, fosfatase ácida e fosfatase alcalina. Solos rizosféricos apresentaram maior atividade microbiana e não foram detectadas diferenças significativas entre os genótipos em todos os parâmetros bioquímicos e de solo avaliados. Os resultados sugerem que o milho $B t$ não afeta negativamente a comunidade microbiana dos solos tropicais. Palavras-chave: milho Bt, diversidade funcional, bioindicadores, qualidade do solo, organismos não alvo. 
Cultivation of genetically modified (GM) crops has experienced rapid expansion in recent years, and continues to grow massively in many countries because of their agronomic advantages and economic benefits. In two decades the global acreage of GM crops has increased from 1.7 million hectares in 1996 to over 181.5 million hectares in 2014 (James, 2014). The Brazilian GM maize acreage increased from 4.9\% (5 million hectare) in 2008/2009 to $81.4 \%$ in $2013 / 2014$, which correspond to 15.83 million hectares (CONAB, 2014). Unfortunately, the rapid expansion of GM crops in many developing countries, driven by farmers, often circumvented biosafety regulatory requirements (Sinebo, 2013). Thus, the potential adverse effects of GM crops on soil microbial communities have been a great concern within the scientific community (Cotta et al., 2013; Silva et al., 2014).

Taking into account $B t$ crops, although many studies have been carried out to determine the possible detrimental effect of $B t$ technology on bacterial communities in soil, the results are very conflicting and did not provide conclusive answers (Baumgarte \& Tebbe 2005; Icoz \& Stotzky, 2007). Thus, the uncertainty about the effects of cry proteins secreted by roots on non-target species in soil remains important arguments against the cultivation of $\mathrm{Bt}$ crops, and deserve further study.

Soil microorganisms are the primary determinant of soil quality and agricultural production through nutrient cycling, soil formation, aggregation of soil particles, fertility, and bioremediation (Singh et al., 2013). Microbial growth in rhizosphere is highly stimulated by root exudates and positively influences soil fertility (Cavaglieri et al., 2009). The plant variety drives the dynamic of the rhizosphere microbial populations which influences the plant growth and health, and the sustainability of the agroecosystem (Dunfield \& Germida, 2004). Therefore, minor alterations in microbial community may affect soil health and ecosystem functioning (Dunfield \& Germida, 2004). The overexpression of $B t$ protein potentially modifies the composition of root exudates of the transgenic plants and additionally may exert a direct effect on non-target species of soil microorganisms (Icoz \& Stotzky, 2007). Consequently, changes in ecological processes and functions mediated by soil microorganisms is one of the potential environmental effects of the recent rapid increase in the global agricultural area cultivated with transgenic crops. The situation is critical in Brazil due the scarce number of studies on the effects of $B t$ maize in tropical soil.

A variety of methods developed to measure soil biological activity give useful information about the ecological status of soil (Fakruddin \& Mannan, 2013; Stefanowicz, 2006). Among them, Biolog and enzyme assays are quite simple, fast and produce reproducible results (Utobo \& Tewari, 2015). The use of available carbon is a key factor modulating the microbial growth in the soil (Garland \& Mills, 1991). Thus, the use of a standardized micro method to perform carbon source utilization tests such Biolog assay provides valuable information about the functional diversity of soil microorganisms (Stefanowicz, 2006; Zak et al., 1994).

The purpose of this study was to evaluate the possible impact of $B t$-maize on soil microbial communities in tropical agrosystem.

\section{Material and Methods Experimental sites}

The work was carried out at Embrapa Maize and Sorghum Research Center, located in Sete Lagoas 


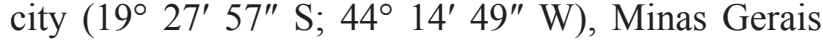
state, Brazil. The climate is characterized by highland tropical climate (hot and warm summers), and dry winters, savannah type, according to the KöppenGeiger classification (Peel et al., 2007), with average annual rainfall of 1.403 inches and the average annual temperature between 22 to $27^{\circ} \mathrm{C}$.

\section{Soil sampling, hybrids and experimental design}

Two types of soil: dystrophic Dark Red Latosol with clay texture from the Brazilian savannah (Cerrado) and lowland (the Brazilian Várzea) hydromorphic soil with clay texture were sampled during the maize flowering stage. Three different maize hybrids from Pioneer were tested: one original non-transgenic (30F35) and two transgenic counterpart expressing the Cry1 Ab protein (30F35Y) and Cry $1 \mathrm{~F}(30 \mathrm{~F} 35 \mathrm{H})$.

The treatments were arranged in a randomized block design with four replicates. Each unit plot consisted of six $5 \mathrm{~m}$ long rows, spaced $0.7 \mathrm{~m}$ apart and plant spaced $0.2 \mathrm{~m}$ in the row. Each soil sample to be tested, rhizosphereandnon-rhizosphere, wascomposed of three subsamples (three plants per plot) collected at the flowering stage and analyzed for metabolic diversity. Enzyme activities of urease, arginase, acid phosphatase and alkaline phosphatase were the criteria used as biological indicators of soil quality.

\section{Enzymatic activities}

The urease activity was determined using the method proposed by Kandeler \& Gerber (1988), which involves the measurement of ammonia released from urea hydrolysis along the incubation period. Arginase activity was determined by measuring ammonia released during the soil incubation with arginine according to method developed by Alef \& Kleiner (1986). The ammonium contents were determined by colorimetric measurements at $660 \mathrm{~nm}$.

The determination of phosphatase activity was according to method described by Alef et al., (1995). For acid phosphatase analysis, the $\mathrm{pH}$ of samples was adjusted to 6.5 with $1 \mathrm{M} \mathrm{HCl}$, and for alkaline phosphatase activity, the $\mathrm{pH}$ was corrected to 11 with $1 \mathrm{M} \mathrm{NaOH}$. The amount of p-nitrophenol (PNP) formed was determined in a spectrophotometer (Labsystems, MultSkan, MS, EUA) at $400 \mathrm{~nm}$. All enzyme determinations were performed in triplicate.

\section{Biolog assay}

The functional diversity of bacterial community was determined by the method developed by Zak et al. (1994). Five grams of each soil sample with three replicates were suspended in $45 \mathrm{ml}$ of saline solution $0.85 \%(\mathrm{w} / \mathrm{v})$ and stirred for 30 minutes at $150 \mathrm{rpm}$ at room temperature. Aliquot of $120 \mu \mathrm{L}$ of diluted samples $\left(10^{-2}\right)$ were inoculated in each well of the Biolog EcoPlate (ECOPLATEâ, Biolog Inc., Hayward, USA) containing three groups of 31 different substrates. The reactions were analyzed by measuring the absorbance at $590 \mathrm{~nm}$ in the Labsystems Multskan Spectrophotometer microplate reader (MS, USA).

Microbial activity in each microplate expressed as average well-color development (AWCD) was used to evaluate the general carbon substrates utilization ability (Garland \& Mills, 1991; Li et al., 2014). Parameters of metabolic diversity of microbial community was estimated by the Shannon diversity index $(\mathrm{H})$ and number of substrate utilized $(\mathrm{S})$ according to Zak et al. (1994). 


\section{Statistical analysis}

All statistical analyses were performed by the software Statistica version. 10.0. The data were standardized by the average well color development (AWCD) in each microplate to remove inoculum density effects (Frąc et al., 2012, Garland \& Mills, 1991) and were investigated by analysis of variance (ANOVA).

\section{Results and Discussion}

Urease and arginase activity

The results of the enzymatic activity assays for urease activity varied between The results of the enzymatic activity assays for urease activity varied between 184.55 and $533.26 \mu \mathrm{g} \mathrm{N}-\mathrm{NH} 4^{+} \mathrm{h}^{-1} \mathrm{~g}$ soil ${ }^{-1}$ (Figure 1), and variation of arginase activity was between 16.22 and $78.14 \mu \mathrm{g} \mathrm{N}-\mathrm{NH} 4+$ $\mathrm{h}^{-1} \mathrm{~g}$ soil $^{-1}$ (Figure 2). However, no significant difference $(\mathrm{p}<0.05)$ was found between $B t$ and non $B t$ genotypes.

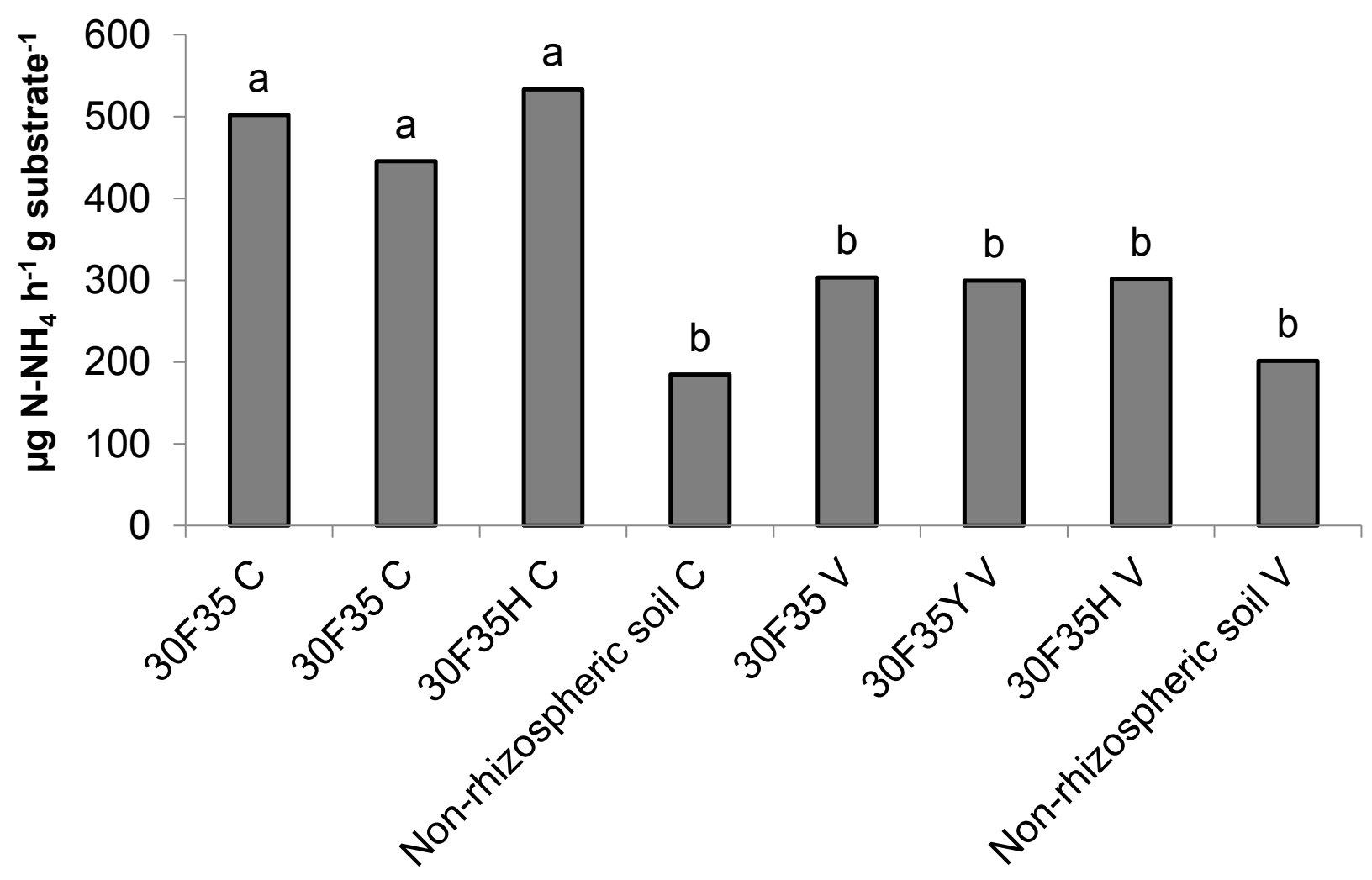

FIGURE 1. Urease activity ( $\mu \mathrm{g} \mathrm{N}-\mathrm{NH}_{4}^{+} \mathrm{h}^{-1} \mathrm{~g}^{-1}$ substrate) in rhizosphere soil of non-transgenic maize hybrid $30 \mathrm{~F} 35$ and its $B t$ isolines 30F35 YC and 30F35HC expressing the Cry $1 \mathrm{Ab}$ and Cry $1 \mathrm{~F}$ proteins of $B$. thuringiensis, respectively, cultivated in tropical Dark Red Latosol of Cerrado (C) and lowland hydromorphic soil with localized flooding (Brazilian Várzea, V). Mean values denoted by the same letter did not differ statistically by Tukey test $(\mathrm{p} \leq 0.05)$. 


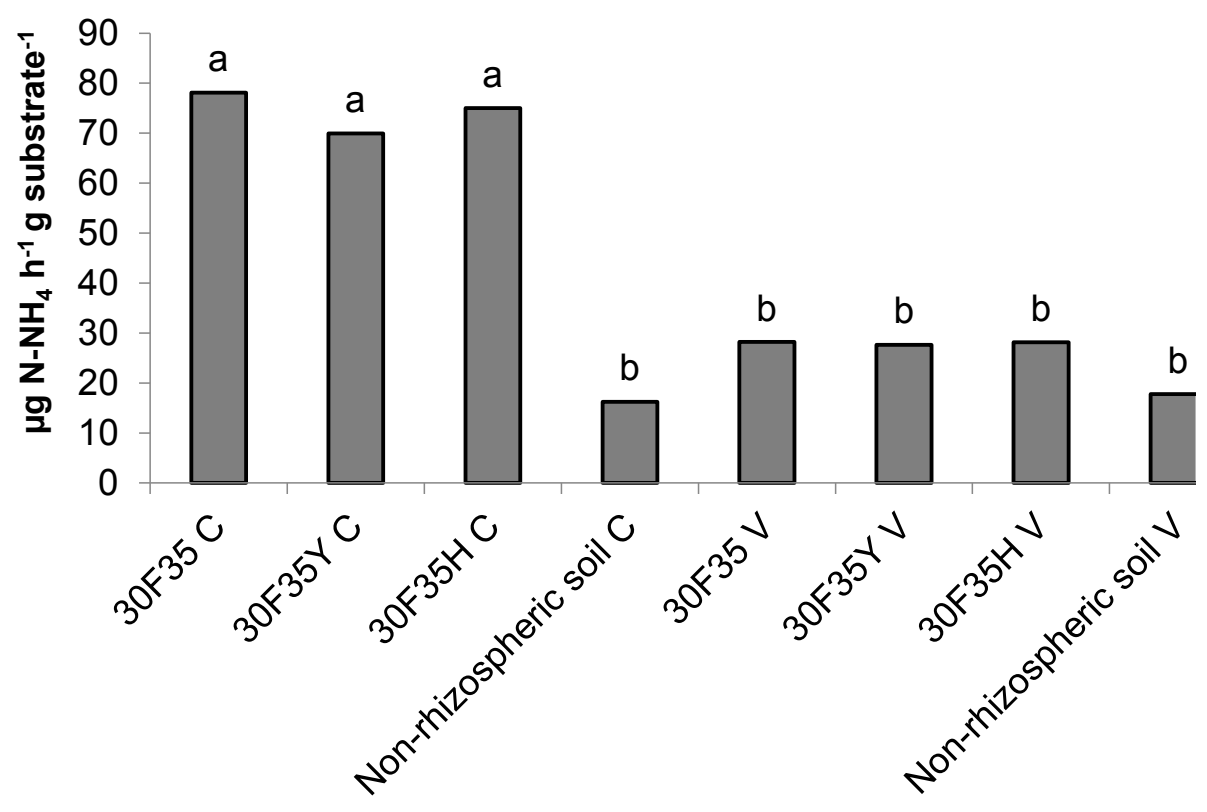

FIGURE 2. Arginase activity ( $\mu \mathrm{g} \mathrm{N}-\mathrm{NH}_{4}^{+} \mathrm{h}^{-1} \mathrm{~g}^{-1}$ substrate) in rhizosphere soil of non-transgenic maize hybrid $30 \mathrm{~F} 35$, and its $\mathrm{Bt}$ isolines $30 \mathrm{~F} 35 \mathrm{Y}$ and $30 \mathrm{~F} 35 \mathrm{H}$ expressing Cry1 $\mathrm{Ab}$ and $\mathrm{Cry} 1 \mathrm{~F}$ proteins of $B$. thuringiensis respectively, cultivated in tropical Dark Red Latosol of Cerrado (C) and lowland hydromorphic soil with localized flooding (Brazilian Várzea, V). Mean values denoted by the same letter did not differ statistically by Tukey test $(\mathrm{p} \leq 0.05)$.

Differences in activities of both enzymes (urease and arginase) were detected among samples of non-rhizosphere and rhizosphere soils of Cerrado. The higher microbial activity in rhizosphere soil of Cerrado was probably due to the presence of more complex organic material such as plant, root debris and the release of root exudates (Frąc et al., 2012). This result supports previous research showing that enzymatic activities are particularly high in the rhizosphere, where root exudates sustain a higher microbial biomass and biochemical activity compared with bulk soils (Frąc et al., 2012).

Microorganisms are the main source of urease in soil and the urease activity is positively and significantly correlated with the microbial biomass (Klose \& Tabatabai, 1999). This enzyme has been used to detect changes in soil quality in different agroecosystems (Klose \& Tabatabai, 1999). As the activity of arginase depends on metabolically active microbial cells, the enzyme activity associated with other microbiological parameters has been considered as a good indicator of the nitrogen status of a soil (Alef \& Kleiner, 1987). In the present study, arginase activity was statistically different between lowland soil and Cerrado indicating that arginase activity is a sensitive quality indicator for tropical soil.

The analysis of enzyme assay data indicated that there were no statistically significant differences 
$(\mathrm{p}>0.05)$ for urease and arginase activities in Red Latosol of Cerrado and lowland hydromorphic soil cultivated with transgenic and non-transgenic maize (Figures 1 and 2). However, soil type significantly influenced $(p<0.05)$ the activity of both enzymes with increased activity observed in Cerrado soil. This indicates that the cycling of nitrogen and consequently the functioning and stability of ecosystems were not significantly affected by the presence of $B t$ proteins in the soil. In a study with $B t$-cotton, Yang et al. (2012) showed that $B t$ protein did not continuously accumulate in the soil, and concluded that $B t$ protein had neither significant influence on urease activity nor significant impact on the contents of organic matter, total nitrogen, and the available nitrogen in the rhizosphere soil.

As expected, in the present study enzyme activities were particularly high in the rhizosphere. The rhizosphere is a microecological zone in direct proximity of plant roots and directly influenced by root secretions (Sylvia et al., 2005). The plant roots and residues, releases of root exudates, living and dead microbes, and soil animals sustain a higher microbial biomass and biological activity in the rhizosphere compared with bulk soil (Li et al., 2014). Up to $15 \%$ of the root surface area is covered with rhizosphere-specific microorganisms providing many sites for biological interactions (Sylvia et al., 2005).

The activity of both, urease and arginase are directly correlated to the capacity of soil in converting organic nitrogen in mineral nitrogen, and the availability of nitrogen to the plants (Alef \& Kleiner 1987; Kandeler \& Gerber, 1988). Native urease in soils is remarkably stable and different soils have different levels of urease activity determined by soil enzymeprotective mechanisms against microbial degradation and other processes leading to enzyme inactivation
(Burns et al., 1972; Zantua \& Bremner, 1977). In temperate climates urease activity in soil is persistent for long periods under low water, low temperature, and sterile regimes (Burns et al., 1972). However, the environmental conditions in tropical regions are very different especially in the summer with a large excess of water and elevated temperatures. In the present study, the high activity of urease suggests that other enzyme-protective mechanisms may exist in tropical soil.

In this study, the enzymatic activity of urease was approximately six times higher than those observed for arginase. This result was predictable because unlike urease which may remain stable for relatively long time, complexed with soil particles and organic matter, the enzyme arginase shows low stability in soil and its activity is critically dependent of metabolically active microbes (Alef \& Kleiner, 1987). Additionally, in soil with high content of organic matter, high potential for decomposition and low $\mathrm{C} / \mathrm{N}$ ratio, arginine, the substrate of arginase, may be used as a source of $\mathrm{C}$ by microbial biomass (Alef \& Kleiner, 1987).

In these cases, the low activity of arginase is due the lack of substrate, even if the population increase or the metabolic activity of cells is high. In contrast, in soils where organic matter is abundant and high $\mathrm{C} / \mathrm{N}$ ratio, the $\mathrm{N}$ released by the reaction of arginase may be assimilated by the microbiota, resulting again in low enzyme activity. Taken together, these conditions may explain, at least in part, the low activity of arginase in the soil samples analyzed.

Arginine mineralization is useful to estimates soil microbial biomass and microbial community structure. Alef \& Kleiner (1987) suggested that under specific conditions, the arginine ammonification rate was proportional to soil microbial biomass. 


\section{Phosphatase activity}

Soil enzyme activity is a potential indicator of soil quality due to its high sensitivity to external factors and ease of measure (Utobo \& Tewari, 2015). Enzyme activity generally increases with the rise of soil organic matter content and higher enzyme activity indicates larger microbial communities and greater stability of enzymes adsorbed on humic materials (Marinari \& Antisari, 2010).

In the present study, regard phosphatase enzymes, significant differences $(p<0.05)$ were not detected among the three genotypes planted in both soil types (Figure 3). The values observed for
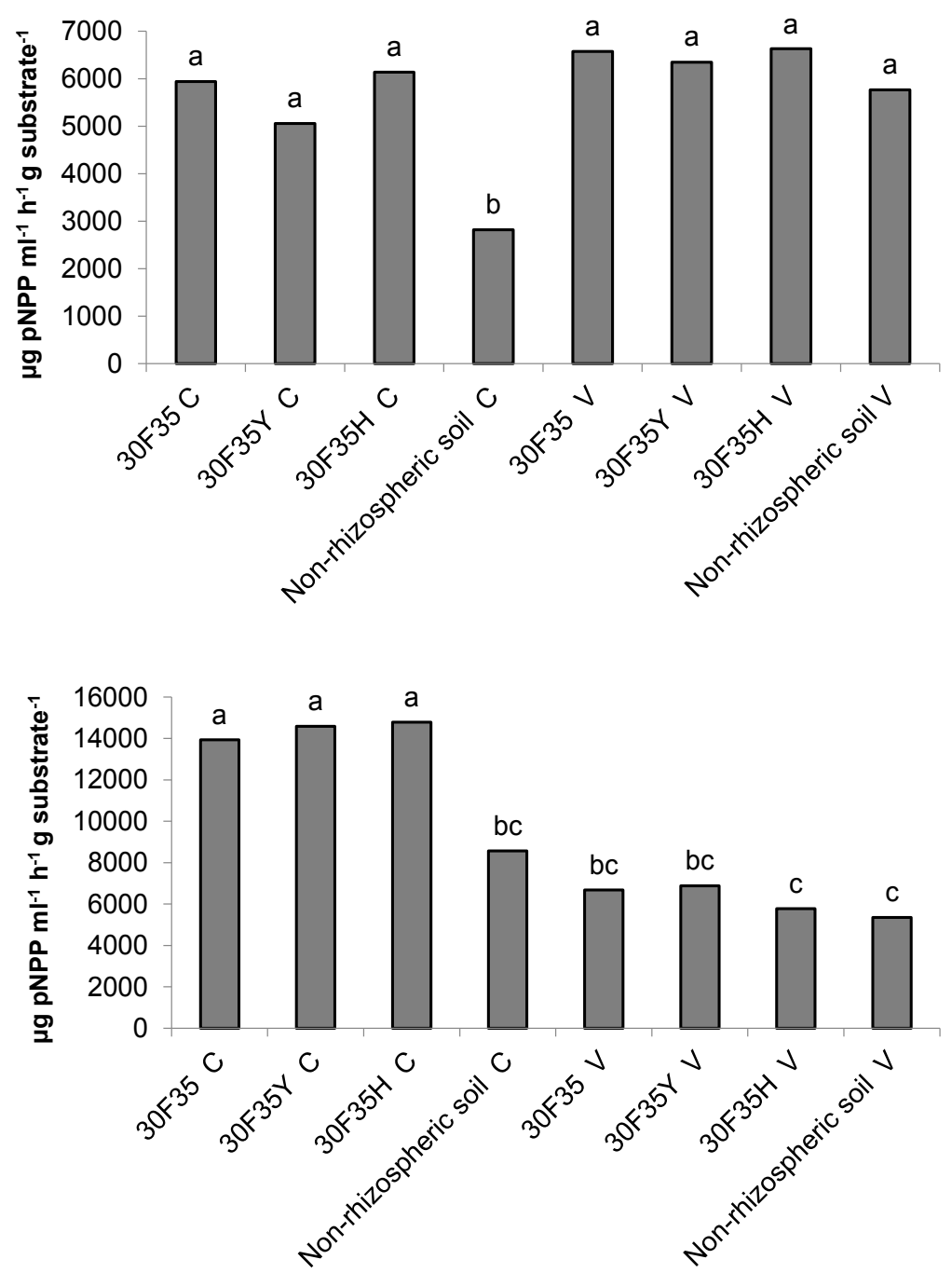

FIGURE 3. Alkaline phosphatase activity (A) and acid phosphatase (B) ( $\mu \mathrm{g} p N P P \mathrm{ml}^{-1} \mathrm{~h}^{-1} \mathrm{~g}^{-1}$ substrate) in rhizosphere soil of non-transgenic maize hybrid 30F35 and its $\mathrm{Bt}$ isolines 30F35YC and 30F35HC expressing the Cry $1 \mathrm{Ab}$ and Cry1F proteins of B. thuringiensis respectively, cultivated in Dark Red Latosol of Cerrado (C) and lowland hydromorphic soil with localized flooding (Brazilian Várzea, V). Mean values denoted by the same letter did not differ statistically by Tukey test $(\mathrm{p} \leq 0.05)$. 
acid phosphatase activity varied between 5.35 and $14.78 \mathrm{mg}$ and alkaline phosphatase between 2.82 and $6.63 \mathrm{mg}$ pNPP $\mathrm{ml}^{-1} \mathrm{~h}^{-1} \mathrm{~g}$ substrate ${ }^{-1}$. Thus, the phosphorus cycling in maize rhizosphere was not influenced by the $B t$ proteins secreted in soil. The alkaline phosphatase activity was significant different only between samples of non-rhizosphere soil of Cerrado which showed the lower values of enzyme activity. Additionally, acid phosphatase activity was significantly lower in lowland soil.

In Brazil, this soil is subject to water-logging and flooding during the rainy season. In flooded soil, the water replaces most air in the soil pores resulting in a drastic reduction in both the oxygen content and in the gaseous exchange capacity (Bell et al., 1998). Thus, flooded soils are predominantly anaerobic environments that limit the microbial access to organic matter and reduce the decomposition rate (Sridevi et al., 2013). Studies have also demonstrated that the soil type and texture are the most important factors for modulate the activity of root-associated microbial community regardless the crop system (Chiarini et al., 1998; Cotta et al., 2014). Brazilian lowland soils have high clay level, with low drainage and aeration capacity, and a high tendency to flooding during the summer period from November to March (Cotta et al., 2013). This unique condition may explain the present result where the acid phosphatase activity was lower in lowland soil compared with Cerrado soil.

\section{Biolog profile}

Results of metabolic activity of soil microbial community showed no significant difference between the total metabolic activity for the use of substrates measured by the Shannon diversity index and $\mathrm{S}$ parameter (total number of substrates used) at 72 hours of incubation (Table 1). The total metabolic activity had no significant difference among the three genotypes in both lowland and Cerrado soil and it was significantly lower in non-rhizosphere soil. Based on parameters studied, it was concluded that $B t$-maize genotypes expressing cry proteins did not negatively impact the functional diversity of tropical soil.

Metabolic profile method has also limitations such as: only the culturable fraction of the community is capable of growing under the experimental conditions (Garland \& Mills, 1991); fast growing microorganisms are dominant in culture media (Yao et al., 2000); inoculum density can directly affect the results (Garland \& Mills, 1991); and it reflects the potential, not the in situ, metabolic diversity (Fakruddin \& Mannan, 2013; Garland \& Mills, 1991).

Currently, all methods used to assess soil microbial diversity and activity present technical limitations difficult to circumvent. These hinder the development of a standard method that can be used in any laboratory to study the effects of Bt protein in the soil microbial community (Kostov et al., 2014).

For now, the use of more than one method to assess soil microbial diversity and activity allows overcome difficulties of each particular one. Moreover, the possible negative effects of cry proteins secreted by roots of $B t$ crops on non-target species in the soil are still unclear. The results with current available methods are contrasting showing both, negative and null effects of $B t$ crops on soil microbial diversity and activity.

The apparent contradictory results on the effects of $B t$ proteins on the soil microbiota possibly reflect both the biological and environmental complexity of each soil and limitations of each method. Thus, different results may represent the transitory status of a particular microbial community for each soil and environment analyzed. 
TABLE 1. Total activity of the microbial population (AWCD), number of used substrates (S), and metabolic diversity (Shannon's substrate diversity Index - H) measured by Biolog assay, 72 hours after incubation of nonrhizosphere and rhizosphere samples of transgenic and non-transgenic maize genotypes cultivated in lowland soil with localized flooding (Brazilian Várzea, V) and tropical Dark Red Latosol of Cerrado (C) soils.

\begin{tabular}{cccc}
\hline Samples* & $\begin{array}{c}\text { Total Activity } \\
\left(\text { AWCD }^{* *}\right)\end{array}$ & S (Number of Substrates) & H (Shannon Index) \\
\hline 30F35 C & $14,46 \mathrm{a}$ & $26 \mathrm{a}$ & $3,08 \mathrm{a}$ \\
30F35Y C & $13,83 \mathrm{a}$ & $29 \mathrm{a}$ & $3,18 \mathrm{a}$ \\
30F35H C & $15,64 \mathrm{a}$ & $27 \mathrm{a}$ & $3,13 \mathrm{a}$ \\
Non-rhizosphere C & $3,88 \mathrm{~b}$ & $9 \mathrm{~b}$ & $1,82 \mathrm{~b}$ \\
30F35 V & $11,51 \mathrm{a}$ & $26 \mathrm{a}$ & $3,05 \mathrm{a}$ \\
30F35Y V & $8,40 \mathrm{a}$ & $27 \mathrm{a}$ & $3,08 \mathrm{a}$ \\
30F35H V & $10,85 \mathrm{a}$ & $26 \mathrm{a}$ & $3,07 \mathrm{a}$ \\
Non-rhizosphere V & $6,18 \mathrm{~b}$ & $22 \mathrm{~b}$ & $2,63 \mathrm{~b}$ \\
\hline
\end{tabular}

*Non-transgenic maize hybrid $(30 \mathrm{~F} 35 \mathrm{C})$, and its $\mathrm{Bt}$ isolines $30 \mathrm{~F} 35 \mathrm{YC}$ and $30 \mathrm{~F} 35 \mathrm{HC}$ expressing the Cry $1 \mathrm{Ab}$ and Cry $1 \mathrm{~F}$ proteins of B. thuringiensis, respectively. Means of three replicates followed by the same letter did not differ statistically by Tukey test $(\mathrm{p} \leq 0.05)$.

** AWCD - average well color development, 590nm.

\section{Conclusion}

In the present study, there was no negative influence of Bt-maize on the functional diversity of the microbial community considering the two types of soil and conditions evaluated. However, considering the existence of many different types of soils in tropical areas where corn is planted, future studies need to be extended to other maize cultivation areas to improve the view of the $B t$-maize effects on the functional diversity of agricultural ecosystems in the tropics.

\section{Acknowledgements}

This work was supported by Embrapa Maize and Sorghum Research Center; Lac Biosafety Project; Brazilian Council for Scientific and Technological Development (CNPq), and Minas Gerais State Research Support Foundation (FAPEMIG).

\section{References}

ALEF, K.; KLEINER, D. Applicability of arginine ammonification as indicator of microbial activity in different soils. Biology and Fertility of Soils, Berlin, v. 5, p. 148-151, 1987.

ALEF, K.; KLEINER, D. Arginine ammonification, a simple method to estimate microbial activity potentials in soil. Soil Biology and Biochemistry, Elmsford, v. 18, p. 233-235, 1986

ALEF, K.; NANNIPIERI, P.; TRAZAR-CEPEDA, C. Enzyme activities: phosphatase activity. In: ALEF, K.; NANNIPIERI, P. (Ed.). Methods in applied soil microbiology and biochemistry. London: Academic Press, 1995. p. 335-344.

BAUMGARTE, S.; TEBBE, C. C. Field studies on the environmental fate of the Cry $1 \mathrm{Ab} B t$-toxin produced by transgenic maize (MON810) and its effect on bacterial communities in the maize 
rhizosphere. Molecular Ecology, Oxford, v. 14, p. 2539-2551, 2005.

BELL, M. J.; MOODY, P. W.; CONNOLLY, R. D.; BRIDGE, B. J. The role of active fractions of soil organic matter in physical and chemical fertility of ferrosols. Australian Journal of Soil Research, Melbourne, v. 36, p. 809-820, 1998. BURNS, R. G.; PUKITE, A. H.; MCLAREN, A. D. Concerning the location and persistence of soil urease. Soil Science Society of America Journal, Madison, v. 36, p. 308-311, 1972.

CAVAGLIERI, L.; ORLANDO, J.; ETCHEVERRY, M. Rhizosphere microbial community structure at different maize plant growth stages and root locations. Microbiological Research, Jena, v. 164, p. 391-399, 2009

CHIARINI, L.; BEVIVINO, A.; DALMASTRI, C.; NACAMULLI, C.; TABACCHIONI, S. Influence of plant development, cultivar and soil type on microbial colonization of maize roots. Applied Soil Ecology, Amsterdam, v. 8, p. 1118, 1998.

CONAB. Companhia Nacional de Abastecimento. Acompanhamento da safra brasileira de grãos: 2014. Brasília, 2014.

COTTA, S. R.; DIAS, A. C. F.; MARRIEL, I. E.; ANDREOTE, F. D.; SELDIN, L.; VAN ELSAS, J. D. Different effects of transgenic maize and nontransgenic maize on nitrogen-transforming archaea and bacteria in tropical soils. Applied and Environmental Microbiology, Washington, v. 80, p. 6437-6445, 2014.

COTTA, S. R.; DIAS, A. C. F.; MARRIEL, I. E.; GOMES, E. A.; VAN ELSAS, J. D.; SELDIN, L. Temporal dynamics of microbial communities in the rhizosphere of two genetically modified (GM) maize hybrids in tropical agrosystems.
Antonie Van Leeuwenhoek, Amsterdam, v. 103, p. 589-601, 2013.

DUNFIELD, K. E.; GERMIDA, J. J. Impact of genetically modified crops on soil- and plantassociated microbial communities. Journal of Environmental Quality, Madison, v. 33, p. 806-815, 2004.

FAKRUDDIN, M.; MANNAN, K. S. B. Methods for analyzing diversity of microbial communities in natural environments. Ceylon Journal of Science, Colombo, v. 42, n. 1, p. 19-33, 2013.

FRĄC, M.; OSZUST, K.; LIPIEC, J. Community Level Physiological Profiles (CLPP): characterization and microbial activity of soil amended with dairy sewage sludge. Sensors, v. 12, p. 3253-3268, 2012.

GARLAND, J. L.; MILLS, A. Classification and characterization of heterotrophic microbial communities on the basis or patterns of community level sole carbon source utilization. Applied and Environmental Microbiology, Washington, v. 57, p. 2351-2359, 1991.

ICOZ, I.; STOTZKY, G. Cry3Bb1 protein from Bacillus thuringiensis in root exudates and biomass of transgenic corn does not persist in aoil. Transgenic Research, London, v. 17, p. 609-620, 2007.

JAMES, C. Global status of commercialized Biotech/GM crops. Ithaca: ISAAA, 2014. 250 p. (ISAAA. Brief n. 49).

KANDELER, E.; GERBER H. Short term assay of soil urease activity using colorimetric determination ammonium. Biology and Fertility of Soils, Berlin, v. 6, p. 68-72, 1988.

KLOSE, S.; TABATABAI, M. A. Urease activity of microbial biomass in soils. Soil Biology and Biochemistry, Elmsford, v. 31, p. 205-211, 1999. 
KOSTOV, K.; KROGH, P. H.; DAMGAARD, C. F.; SWEET, J. B.; HENDRIKSEN, N. B. Are soil microbial endpoints changed by $B t$ crops compared with conventional crops? A systematic review protocol. Environmental Evidence, v. 3, p. 1-11, 2014.

LI, X.; RUI, J.; MAO, Y.; YANNARELL, A.; MACKIE, R. Dynamics of the bacterial community structure in the rhizosphere of a maize cultivar. Soil Biology and Biochemistry, Elmsford, v. 68, p. 392-401, 2014.

MARINARI, S.; ANTISARI, L. V. Effect of lithological substrate on microbial biomass and enzyme activity in brown soil profiles in the Northern Apennines (Italy). Pedobiologia, Jena, v. 53, p. 313-320, 2010.

PEEL, M. C.; FINLAYSON, B. L.; MCMAHON, T. A. Updated world map of the Köppen-Geiger climate classification. Hydrology and Earth System Sciences, v. 11, p. 1633-1644, 2007.

SILVA, D. A. F.; COTTA, S. R.; VOLLÚ, R. E.; JURELEVICIUS, D. A.; MARQUES, J. M.; MARRIEL, I. E.; SELDIN, L. Endophytic microbial community in two transgenic maize genotypes and in their near-isogenic nontransgenic maize genotype. BMC Microbiology, v. 14, p. 1-9, 2014.

SINEBO, W. Adoption processes and regulatory challenges for genetically modified crops in developing countries: lessons for Africa. Ouagadougou: NEPAD, 2013. (Policy Brief. Agricultural Biosafety, 1).

SINGH, D.; JAIN, P.; GUPTA, A.; NEMA, R. Soil diversity: a key for natural management of biological and chemical constituent to maintain soil health \& fertility. International Journal BioScience and Bio-Technology, v. 5,p.41-50,2013.
SRIDEVI, A.; RAMANKRISHNAN, B.; SANDY, A.; NARASIMHA, G. Bacterial population and their metabolic activities in flooded rice soil. Annals of Biological Research, v. 4, n. 6, p. 111-118, 2013.

STEFANOWICZ, A. The biolog plates technique as a tool in ecological studies of microbial communities. Polish Journal of Environmental Studies, v. 15, n. 5, p. 669676, 2006.

SYLVIA, D.; FUHRMANN, J.; HARTEL, P.; ZUBERER, D. Principles and applications of soil microbiology. New Jersey: Pearson Education, 2005.

UTOBO, E. B.; TEWARI, L. Soil enzymes as bioindicators of soil ecosystem status. Applied Ecology and Environmental Research, v. 13, p. 147-169, 2015.

YANG, W.; ZHANG, M.; DING, G. Effect of transgenic $B t$ cotton on bioactivities and nutrients in rhizosphere soil. Communications in Soil Science and Plant Analysis, New York, v. 43, p. 689-700, 2012

YAO, H.; HE, Z.; WILSON, M. J.; CAMPBELL, C. D. Microbial biomass and community structure in a sequence of soils with increasing fertility and changing land use. Microbial Ecology, New York, v. 40, p. 223237,2000

ZAK, J. C.; WILLIG, M. R.; MOORHEAD, D. L.; WILDMAN, H. G. Functional diversity of microbial communities: a quantitative approach. Soil Biology and Biochemistry, Elmsford, v. 26, p. 1101-1108, 1994.

ZANTUA, M. I.; BREMNER, J. M. Stability of urease in soils. Soil Biology and Biochemistry, Elmsford, v. 9, p. 135-140, 1977. 